\title{
Albania's European Integration Process and the Impact it Has on the Business Climate between Albania and Italy (Vlora City Case)
}

\author{
Dr. Zamira Sinaj
}

PhD. Rezarta Hasanaj

Prof. Dr. Fatmir Memaj

\section{Doi:10.5901/ajis.2016.v5n3s1p558}

\section{Abstract}

Economic and political links between Albania and Italy dating back hundreds of years before Christ. Have had ups and downs with significant impact while maintaining a constant continuity with each other. Modern relationships, of about 100 years, had some sort of patronage of Italy affected by the development of Albania low following a series of historical events. Relations between the two countries culminated during the reign of King Zog in Albania, followed by a dark period with the start of World War II and the rule of the Communist regime in Albania. Italy regained his place important economic and trade policy relationships with the arrival in Albania on democracy country, becoming one of the most important strategic partners. This paper is abaut the facilities that the Albanian economy has benefited from the EU integration process.

Keywords: EU custmos policy, Roles of Governments, European Community, Situation in Albania, The business environment

\section{Economic Cooperation with Italy}

The cooperation between Albania and Italy is strong and durable, and exceptional relations based on historical, cultural and economic. Italian Development Cooperation (KIZH) is present in Albania since 1991, to support social and economic development of the country through programs aimed at strengthening of production systems, to connect with regional networks of infrastructure, promotion of sustainable management of resources and strengthening institutional capacity together with social, education and health.

As Italy, as well as Albania they have pledged to support and participate actively in the donor harmonization and aid coordination process by fully implementing the principles laid down by the resolution of Monterrey (March 2002), further emphasized by the subsequent Rome Declaration on 'harmonization (in February 2003), the Paris Declaration on aid effectiveness (March 2005), the Accra agenda for action (September 2008) and the partnership for development of Busan (December 2011). As a facilitator of the Fast Track Initiative of the EU Division of Labour of Albania, Italy has helped the Albanian Government in launching this initiative (FT-DOL). In 2010, he accepted and signed a Memorandum of Understanding (MoU) between the Albanian Government and the donor community of the EU, which determines the main donors in each sector. Italy has been designated as the lead donor for the development of the private sector, and has been recognized as a contributor in question and donors active in the Department of Social Development (Employment / AFP, Gender Equality, social inclusion, health and education) and agricultural and rural development.

Table 1. Data on trade with Italy

\begin{tabular}{|l|c|c|c|c|c|c|c|c|}
\hline Italy (Mio Euro) & $\mathbf{2 0 0 7}$ & $\mathbf{2 0 0 8}$ & $\mathbf{2 0 0 9}$ & $\mathbf{2 0 1 0}$ & $\mathbf{2 0 1 1}$ & $\mathbf{2 0 1 2}$ & $\mathbf{2 0 1 3}$ & $\mathbf{2 0 1 4}$ \\
\hline Exsports (E) & 547.07 & 564.97 & 469.53 & 591.73 & 755.76 & 779.89 & 813.81 & 950.32 \\
\hline Imports (I) & 833.21 & 945.46 & 813.1 & 969.72 & 1195.17 & 1206.19 & 1214.82 & 1174.35 \\
\hline Trade volume & 1380.28 & 1510.43 & 1282.63 & 1561.45 & 1950.93 & 1986.08 & 2028.63 & 2124.67 \\
\hline Trade deficit (E-I) & -286.14 & -380.49 & -343.57 & -377.99 & -439.41 & -426.3 & -401.01 & -224.03 \\
\hline Coverage ratio & 65.66 & 59.76 & 57.75 & 61.02 & 63.23 & 64.66 & 66.99 & 80.92 \\
\hline
\end{tabular}

Source: INSTAT

Italy is the most important trade partner for Albania. And 'the partner with the largest share of exports to Albania, which 
occupies $46.3 \%$ in 2013 from $51.1 \%$ in 2012. The products that have dominated Albanian exports for $2009-2011$ are the active processing exports of textiles and footwear. While in 2012-2013, there is a decrease of exports of these products, an increase in groups of mineral products due to higher chrome ore exports. The weight of imports from Italy continued to grow over the past five years, reaching 33\% in 2013 from 26\% of total imports was in 2009.

Italy continues to be the main partner in trade of Albania, while maintaining stability with the growing trend. Also in 2014 , the volume of trade which covers $36 \%$ of the total. The largest increase was in exports to the extent of $16.6 \%$ compared to 2013 while imports fell by $-3.5 \%$

Table 2: ctive foreign enterprises and Joint (Albanian + foreign) by the state and counties

\begin{tabular}{|c|c|c|c|c|c|c|c|c|c|c|c|c|c|}
\hline & 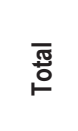 & 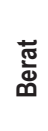 & $\begin{array}{l}\text { :'ळ } \\
\text { 言 }\end{array}$ & 造 & 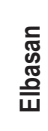 & 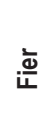 & 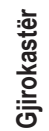 & 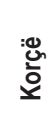 & 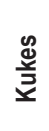 & :₫ & $\begin{array}{l}: \bar{d} \\
\frac{\bar{d}}{0} \\
\frac{\bar{z}}{\omega}\end{array}$ & 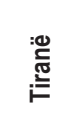 & 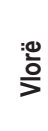 \\
\hline Total & 4,654 & 30 & 14 & 524 & 111 & 126 & 58 & 125 & 20 & 79 & 158 & 3,200 & 209 \\
\hline Italy & 1,903 & 17 & 4 & 309 & 41 & 68 & 11 & 11 & & 47 & 95 & 1,181 & 116 \\
\hline
\end{tabular}

Source: INSTAT

The following table shows annual direct Italian investments in Albania title. The items are in millions of Euros.

\begin{tabular}{|l|c|c|c|c|c|c|c|}
\hline Description of indicators & $\mathbf{2 0 0 7}$ & $\mathbf{2 0 0 8}$ & $\mathbf{2 0 0 9}$ & $\mathbf{2 0 1 0}$ & $\mathbf{2 0 1 1}$ & $\mathbf{2 0 1 2}$ & $\mathbf{2 0 1 3}$ \\
\hline Italy & 220.1 & 321.46 & 347.86 & 386.79 & 427.36 & 124.77 & -132.82 \\
\hline Total FDI & $1,829.58$ & $2,061.15$ & $2,261.44$ & $2,435.97$ & $3,399.90$ & $3,261.53$ & $2,854.19$ \\
\hline
\end{tabular}

Source: Bank of Albania External Sector Statistics

Interest is important Italian companies in the mechanical and IT industry which will allow a variety of industry development and economic sectors.

Great opportunities for Italian companies in the fields of various not supplied such as infrastructure, environment, water supply and sanitation sector, tourism, enegjia, ICT. Of course, the production, the sector in particular fason, represents another important opportunity to strengthen trade and economic relations between Italy and Albania. Increase competition and the challenges of a clock with the macroeconomic situation created, it triggered a reorganization of the sector-oriented products with higher quality and more advanced from a technological point of view. Therefore, it is clearly in need of internationalization of Italian businesses in areas with lower costs, such as Eastern Europe, East Asia and North Africa. In this regard, Albania, a country close to Italy, offers significant opportunities not only in terms of wing cheap labor, but also in specialist Albanian companies at different stages in the process of producing publications, thus ensuring a top products quality.

the ICE Office of Tirana has the mission to facilitate the internationalization of SMEs, providing information and delivery services. ICE is the implementing agency of the Law 84/2001 which regulates the Italian participation in the stabilization, reconstruction and development of countries in the region, including Albania. Under this law, the Office of Tirana is the active monitoring of the various funds (national, European and international) and the coordination of interventions by the European and international initiatives.

Google Translate for Business:Translator ToolkitWebsite TranslatorGlobal Market Finder

\section{The Vlora Region in Space between Two States}

Vlora has a natural connection with Italy is the closest geographic point for the shipment to be one of the most Albanian cities tied with Italy, for historical reasons. Via the port of Vlora we provided goods and passengers every day with the Adriatic coast of Italy, mainly in the region of Puglia.

Valona had approximately 80 companies with Italian capital where we can mention the company Petrolifera Italo Albanian, Orikumi marina, GFA Asphalt, Vlora Confection, bank branches Intesa San Paolo and the Veneto Banca, etc.

Vlora is located in the base of the Italian Konfindustrias offices in the country and expects the Italian consulates in 
Albania. Both of these institutions have been and remain a factor in the promotion of bilateral cooperation.

A good part of the bilateral agreement between the governments was the subject of investment in the Vlore region, where the best example is the project of the port of Vlora. Part of the investment was directed to the restoration and maintenance of monuments of culture and cultural heritage.

Vlora has important natural resources that offer ample opportunities investimi.The region has reserves of oil, natural gas, bitumen and salt. natural conditions offer good opportunities for the production of olives and olive oil produced, the result of all kinds as a source of grape wine, oats, honey, corn, cotton, etc.

Italian language is widely spoken by the people of the region, which in addition to the space for cultural cooperation creates incentives for capital investment came from Italy. A significant number of students have chosen Italy for their education oriented by knowledge of immigration .part language is in Italian. The latter has helped to channel a portion of remittances in the South. The contingent of immigrants with the financial resources provided in Italy have invested in Vlora bringing a part of the culture and products of the Italian country.

According to the Gross Domestic Product by Region for 2013 published by INSTAT, the region of Vlora is the fifth important place in Albania after Tirana, Fier, Durres and Elbasan in terms of gross production.

Table 7: GDP 2013

\begin{tabular}{|c|c|c|c|}
\hline \multirow{2}{*}{ Region } & \multicolumn{2}{|c|}{ GDP at current prices (million leks) } & GDP Real growth growth \\
\cline { 2 - 4 } & $\mathbf{2 0 1 2}$ & $\mathbf{2 0 1 3}$ & $\mathbf{2 0 1 3 / 2 0 1 2}$ \\
\hline Republic of Albania & $1,332,811$ & $1,350,555$ & 1,11 \\
\hline South & 416,251 & 422,287 & 1,2 \\
\hline Vlora & 82,425 & 80,792 & $-1,4$ \\
\hline
\end{tabular}

\section{Source: INSTAT}

Regarding the structure of gross domestic product, Vlora has the most developed agricultural activities, followed by the construction and catering trade. Based on the comparison of the data in the region of Vlora in Albania in all, it seems that Vlora has not fully exploited its potential in trade, transportation and hospitality, even though it is an important point that connects the southern region of the country, has the the most important ports and has a wide and attractive coastline. All these factors must have played a more important role in the development of Vlora.

\subsection{FDI in Vlora}

Official information on the distribution of foreign direct investments in Albania by region is lacking. The information requested is only possible to find a 2006 edition of the Bank of Albania, which analyzes foreign investment in retail in the country in 2004. Based on this analysis, by 2004 the Vlora region can only withdraw 4\% of Foreign investment in the country. Vlora is then places like Gjirokastra, Elbasan and Shkodra, leaving behind not only from Tirana and Durres, which absorbed $67 \%$ of foreign direct investment, but also from Korca and Fieri.

\section{Source: Bank of Albania}

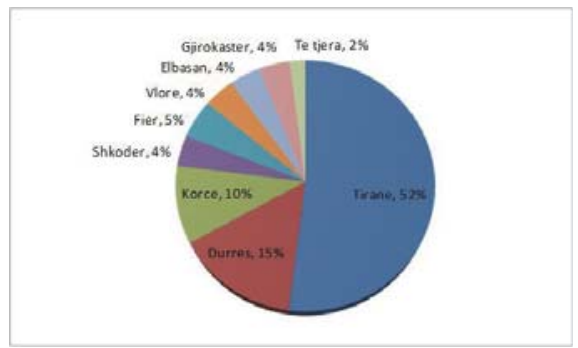

It is estimated that it is important to carry out further analysis to figure out who were the positive factors that have made the attraction of foreign direct investment in some regions and which were hindering factors to attract foreign direct investment in some other regions. FAKORA among them who they have contributed to a relatively low attraction of 
foreign direct investment in Vlora, which is considered as one of the regions with the most development potential in the country.

\subsection{Investment in accommodation capacities}

According to data of the district of Vlora now we operate 128 rooms, of which:

- With 1-10 are 67 rooms with beds 2846 accommodation units or $80 \%$ of total

- With 10-20 rooms are 42 apartments

- With $20-30$ rooms are 13 units with 1304 beds or $16 \%$ of total

- With 30-40 are 3 rooms accommodation unit

- With over 40 rooms are only 3 units with 464 beds or $4 \%$ of the total

- Number of beds for all units is 4614 .

The number of travel agencies has been increasing year by year and today in the district of Vlora 20 this function.

Spaces for tourist development of Vlora

Tourism remains the sector with the highest pontencialin for the development of the territory and its development in the Vlore region was the main objective of all the central and local governments. According to official data published about a third of the income generated by tourism.

However, the potential of many natural and historical that exist are not administered properly, such as in infrastructure, hotels and services, organizing urban population centers, preserving the environment, the activities to promote the right of choice available, etc .

Other problems related to the development of the difficulties of this sector, with electricity supply, inadequate road infrastructure, the presence of the informal economy elements that lead to increased costs to businesses and inhibit proper development. Similarly the problems of the judicial system, the pazgjidhuara conflicts over land ownership, bureaucracy and corruption of customs and taxation and other administrative issues that deal with other businesses that are facing difficulties in terms of business.

\subsection{Geographic location}

Vlora has a favorable geostrategic position of some other countries. His appearance in the sea creates the opportunity for fast connections to Europe via Italy. Bay of Vlora forefront panoramic entrance Sazan Island, which was opened recently by the government to be visited by tourists, and the Karaburun peninsula with which Vlore keeps a key position to the Strait of Otranto.

Vlora Bay has many natural resources, rich biodiversity and ecological corridors. Vlora city lies between the cold water and Zvernec. The plane in which the city of Vlora height from 6 meters to 76 meters above sea level. The length of the coastline is $90 \mathrm{~km}$ from the mouth of the Vjosa until Karaburun part revealed that the government as a priority area for the development of tourism. Currently, the city of Vlore continues to expand in all directions, especially to the shore especially towards Jonufrës and cold water.

\subsection{Port development}

Region which preserves an ancient name was mentioned by a number of historians. Vlora Bay is mentioned for the role they had initially important port of Orikum and subsequently Aulonën. At different times of boom periods referred to shipping arrangement, as well as the input output, to a wide range of goods provided substantial assistance to the area's economy. agricultural products produced in the area and the border regions as recognized Mallakaster Myzeqeja or increased exports through the port of Vlora. In today's situation it offers opportunities which are not yet exploited all their skills.

\subsection{Sights of nature}

National park near Vjosë Pish-Poros in Vlore on the Adriatic Sea has an area of 1,770 hectares. Llogara National park in Vlora, at the foot of Mount Cika, has an area of 1010 hectares, it is one of the most attractive tourist destinations for locals and foreigners.

Island Zvernec monument of culture, declared by the Albanian government, the hills with olive groves, woods Soda 
and its lagoon and the island of Sazan.

Vlora coast Narta lagoon and found Orikumi. Narta lagoon has a 41.8 square kilometers. This area receives solar radiation at high around 2761.9 hours of sunshine annually. natural habitats in this area constitute a special meaning. The biodiversity of this lagoon is too high and its importance, the scale second only to Karavasta republic. Projects in the Albanian coastal zone management and the lagoon is included, that beyond the effective fishing, includes about 75 species of algae and micro.

natural monuments including many living objects of nature, such as trees of special features that bring the scientific, aesthetic, recreational and tourism: Palasa plan at sea, etc. Pine flag in Llogara. Flag Pine in Llogara, has taken on the appearance of the flag where the wind effect, is $20 \mathrm{~m}$ high with a $75 \mathrm{~cm}$ diameter and 105 years.

Caves are another object of the spine already exists in the nature of the area where the cave of which Kurvelesh Petes Lek, Haji Ali Karaburun caves, grottos and caves Lepenica Velca in Vlore. Cave while Velca Vlora bear traces of the Illyrian culture. Since the '30s, areologu Italian Pirro Marcone says. "Settlements first Velca cave as he and others in the Balkans, providing a rich archaeological material indicating the culture of primitive peoples, their working tools, customs and pagan rites beliefs, "Welch said there are several caves in the cave Skotës, Macie cave, the stone cave, which have attracted the attention of cavers and tourists. Cave of Haji Ali, is located northwest of the Karaburun Peninsula, near Cape Gjuhzës. To its input has a width of 10 meters and a height of 10-15 m. This cave served as a refuge for sailors in stormy moments. The cave was named Haji Ali sea captain from Ulcin, who was one of the most skilled soldiers of the Turkish navy in the Mediterranean.

\subsection{Archaeological Parks}

Orikum Archeological Park. This archaeological park contains a particular value because it traces the early development paragrek, Greek and Roman. In the fifth century BC, it was one of the largest ports of the Adriatic Sea, which has become one of the most important battles of the Romans against Illyrians maqedonësve. Ështëzhvilluar in this country one of the battles between Pompey and Julius Caesar perandorëveromakë. Near the center it is also archaeological Marmiroi Church and the domes of the 12th century, the floor, which has the shape of a cross.

Amanties archaeological park, located $25 \mathrm{~km}$ depth environmental Vlora huge sums archaeological wealth of tourist. Until the third century BC was one of the most important centers of political, economic and cultural amant tribe. Archaeological excavations have brought to light the old stadium with 1500 seats Olympics, akroplin, the walls, the temple of Aphrodite, etc. Near the historic center, near Kota is the ancient city of Olympia.

\section{Advantages and disadvantages of investing in Vlora}

\subsection{Advantages}

- Geographic location

- The presence of natural resources

- The presence of tourism potential and tradition of hospitality

- The presence of monuments

- Presence of resources conducive to the development of agribusiness and agro-tourism

- The tradition in crafts and trade

- low labor costs

- The average age of the young population

- $\quad$ The presence of the University "Ismail Qemali" University Collection "Independence", etc. Commercial High School.

- The presence of vocational training centers

- The presence of a supportive community changes

- The process of decentralization. of true writing and its economic development strategy

- National strategies to support small and medium-sized

- The presence of ancillary services such as bank branches 


\subsection{Disadvantages and difficulties}

- Issues mentioned that the discomfort companies

- Lack of projects for the development of tourism

- Low occupancy

- There is a mismatch in the demand for training and professional qualification, with territorial training offer

- The lack of enforcement of planning legislation by the NCRT and local legislation

- mismanagement of public property and their lack of registration

- engineering Depreciation cities

- Low level of implementation of the projects and their control

- The lack of control over the territory of the Municipality

- illegal interventions in the provision of drinking water and electricity distribution network Network

- The low level of local revenue

- Lack of transparency

- The lack of a strategy for environmental protection - The lack of capital investment by the central government,

- The lack of adequate infrastructure

- The presence of informal market and tax evasion

- The lack of a security policy for the internal market

- High corruption

- Migration from rural areas and forced migration of brain

\section{Conclusions and Recommendations}

Vlora has many natural and historical potential, but numerous problems continued and reduce the opportunities for tourism development and the transformation of these potential, Vlora as a reference point for the tourist destination. While tourism has remained projects, the beaches are polluted and is epapërshtatshme infrastructure. Many buildings are made without adding more criteria. holiday costs are equal or perhaps greater than in neighboring countries.

To create a suitable and sustainable tourism development environment should government intervention and local support for the following:

- Improve infrastructure;

- Orientation spending function to create services for area businesses

- The promotion of auxiliary services for tour operators

- Environmental Protection

- the promotion of a convenient marketing or tourist guides

- Attracting foreign investment in the tourism sector

In terms of tourism development in the Mediterranean region is the growing competition between points dukeu tourists are becoming more intense. This intensity brings the need to adapt to market developments and customer expectations. The presence of cultural diversity of the country and natural and historical possibilities that the area offers combined with the low cost of labor will have to return to a competitive advantage Vlora.

\section{References}

ACIT Symposium, Tirana, Albania, December 2003.

Edwards, S. , \& Lederman, D. (1998). The Political Economy of Unilateral Trade Liberalization: The Case of Chile. Cambridge: National Bureau of Economic Research.

Evropean Commission (2007), Economic Papers

Evropean Commission. (2007). Steps towards a deeper economic integration:the Internal Market in the 21st century. A contribution to the Single Market Review. Brussels: Evropean Commission.

Kaldor, N. (1978). Further Essays on Economic Theory. London.

Kastrati P., Revista Shqiptare Social Ekonomike, Prill, 2014.

Kathuria, S. (2008). Western Balkan Integration and the EU: An Agenda for Trade and Growth. Washington: World Bank.

Krueger, A. O. (1997). Trade Policy and Economic Development: How We Learn. Cambridge: National Bureau of Economic Research. 
Miesner, U. (2009). Contributions of quality infrastructure to regional economic integration. Germany: Physikalisch-Technische Bundesanstalt.

Ministria e Zhvillimit Ekonomik, Turizmit, Tregtisë dhe Sipërmarrjes

Mohsen Tavakol et al. Making sense of Cronbach's alpha International Journal of Medical Education. 2011; 2:53-55 Editorial ISSN: 2042-6372 DOI: 10. 5116/ijme. 4dfb. 8dfd 532011

Thirwall, A. (1998). The Balance of Payments and Growth: From Mercantilism to Keynes to Harrod and Beyond. New York: St. Martinës Press. 